\title{
Bir Okul Öncesi Öğretmeninin Fen Öğretimine Yönelik Pedagojik Alan Bilgisinin Keşfedilmesi*
}

\section{Exploration of The Pedagogical Content Knowledge of a Preschool Teacher on Science Teaching}

\begin{abstract}
Semanur NACAR**, Ali Yiğit KUTLUCA***
Öz: Bu araştırmanın amacı, yüksek lisans öğrenimine devam eden bir okul öncesi öğretmeninin fen öğretimine yönelik pedagojik alan bilgisini (PAB) keşfetmektir. Araştırma devlet anaokulunda görev yapmakta olan bir okul öncesi öğretmeninin katılımıyla gerçekleştirilmiştir. Bu araştırmada durum çalışması deseni kullanılmıştır. Böylece bir okul öncesi öğretmeninin fen öğretimine yönelik pedagojik alan bilgisi incelenmiş ve herhangi bir konuya yönelik pedagojik kavramsallaştırmasının altında yatan nedenler tespit edilmiştir. Katılımcıdan seçtiği bir fen konu alanı özelinde ders planı oluşturması, PAB'a yönelik görüşme sorularını cevaplaması ve oluşturmuş olduğu ders planını uygulaması istenmiștir. $\mathrm{Bu}$ şekilde araştırmanın verileri toplanmıştır. Katılımıının öğretim etkinliği ders planı ve PAB görüşme sorularına verdiği yanıtlar, tümevarımsal içerik analizi yöntemi ile analiz edilip sınıf içi öğretimi ise gözlem rubriği aracılı̆̆ıla değerlendirilmiştir. Veri analizleri sonucunda, katılımcının fen öğretimi konusunda yeterli bilgiye sahip olmadığ 1 ve bu durumun PAB haritasına yansıdığı tespit edilmiştir. Bu öğretmenin PAB haritasında pentagon modelini tamamlayamadığı ortaya çıkmıştır. Buna göre öğretmenin fen öğretimine yönelik PAB bileșenlerinin çoğu arasında çok zayıf bağlar bulunmaktadır. Sınıf içi gözlem bağlamında ise öğretmenin teorikte bilgi birikimi olmasına rağmen bu durumu uygulamaya yansıtamadığı ortaya çıkmıştır. Ulaşılan sonuçlar, okul öncesi eğitim, fen eğitimi ve PAB literatürü temelinde tartışılmıştır. Ayrıca bu sonuçlar çerçevesince okul öncesi fen öğretimi bağlamında öneriler verilmiştir.
\end{abstract}

Anahtar Kelimeler: Okul öncesi eğitimi, fen öğretimi, okul öncesi öğretmeni, pedagojik alan bilgisi

\begin{abstract}
The aim of this study was to explore the pedagogical content knowledge (PCK) of a master's degree recipient preschool teacher on science teaching. The study was conducted with the participation of a preschool teacher working in a public kindergarten and was designed as a case study. Thus, the pedagogical content knowledge of a preschool teacher on science teaching was investigated and the underlying reasons of her pedagogical conceptualization of any subject were detected. The participant was asked to create a lesson plan for a science subject of her choice, answer the interview questions regarding PCK and implement her lesson plan, and data was collected. The participant's responses to teaching activity lesson plan questions and PCK interview questions were analyzed by using an inductive content analysis method and her in-class teaching was assessed using an observation rubric. As a result of data analysis, it was found that the participant did not have sufficient knowledge of science teaching which was reflected in her PCK map. In the context of in-class observation, it was revealed that although the teacher had theoretical knowledge, she failed to put this knowledge into practice. It was determined that this teacher could not complete the pentagon model in the PCK Map. Accordingly, there are very weak bonds between most of the PCK components of the teacher for science teaching. The results are discussed based on pre-school education, science education and PCK literature. Also, within the framework of these results, suggestions are given in the context of preschool science teaching.
\end{abstract}

Keywords: Preschool education, science teaching, preschool teacher, pedagogical content.

\footnotetext{
* Bu makale, birinci yazarın 'Yüksek Lisans Öğrenimine Devam Eden Okul Öncesi Öğretmenlerinin Fen Öğretimine Yönelik Pedagojik Alan Bilgilerinin İncelenmesi' isimli yüksek lisans tezinden üretilmiştir.

** Öğretmen, İstanbul-Türkiye, ORCID: 0000-0002-2767-4289, e-posta: semanacar1996@gmail.com

*** Dr. Öğr. Üyesi, İstanbul Aydın Üniversitesi, Eğitim Fakültesi, İstanbul-Türkiye, ORCID: 0000-0002-1341-3432,

e-posta: alikutluca@aydin.edu.tr
} 


\section{Giriş}

Çocuklar dünyaya geldikleri andan itibaren çevrelerinde olup bitenleri tanıma, içinde bulundukları dünyayı anlamlandırma gereksinimi duyarlar. İçlerinde var olan bu doğal merak sayesinde ise bazı basit bilimsel becerileri geliştirirler. Çocukların bu merak duygusuyla yaşadıkları çevreyi anlamlandırmaya ve tanımaya ilişkin çabaları yaşamlarının ilk fen deneyimlerini oluşturur (Aktaş-Arnas, Aslan ve Bilaloğlu, 2014). Okul öncesi dönemdeki eğitim başta olmak üzere her eğitim kademesinde çocukların merak ettikleri önemsenmeli (Kahraman, Ceylan ve Ülker, 2015) zaman içinde karşılaşabilecekleri problemleri tanımlamalarına ve durumlar arasında neden sonuç ilişkisi kurmalarına olanak sağlanmalıdır (Uludağ, 2017). Araştıran, inceleyen, üretken bireyler yetiştirebilmek için fen öğretimine gereken vakit ayrılmalı, çok yönlü ve detaylı bir eğitim programı hazırlanmalı; programlar çocukların ihtiyaçlarına yönelik şekillenmelidir. Tüm bunları gerçekleştirebilmek için okul öncesinde fen öğretiminin önemi iyi kavranmalı, çocuklara temel fen bilgi ve becerilerinin kazandırılması amaçlanmalıdır çünkü yaşamın bu kıymetli dönemlerde geciktirilen temel bilgiler çocuklara daha sonraki yıllarda verilmeye çalışılıp, çok fazla bilgi ve beceriyle donatılsa bile gelinen düzeyde gerilemeler olası olduğundan fen çalışmalarına gereken önemin verilmesi gerekmektedir (Sansar, 2010).

Fen çalışmaları çocukların deneyimleyerek, yaparak ve yaşayarak öğrenmesini, bilgi birikimi yapmalarını, gözlem ve deney yeteneklerinin gelişmesini, hayatlarında karşılaştıkları her duruma karşı daha duyarlı olmalarını ve dikkatli gözlem yapmalarını sağlamaktadır (Sundqvist ve Nilsson, 2018). Yetişkinler için olduğu gibi çocuklar için de fen çalışmaları günlük yaşamın kolaylaşması ve bireylerin var olan becerilerini geliştirmesi açısından gereklidir. Bu çalışmalarla çocukların; gözlem yapma, iletişim kurma, tahminler yürütme, gibi zihinsel süreç becerileri desteklenir. $\mathrm{Bu}$ sayede çocuklar; öğrenirken aynı zamanda öğrendiklerini başka bir konuya aktarabilirler, dikkatle gözlem yapar, tahminde bulunur, diğer arkadaşlarını test eder, sorular sorar, arkadaşları ve öğretmenleri ile etkileşime girerler (Sak, Tantekin-Erden ve Morrison, 2018). Kurulan etkileşimlerle, çocuklardaki bilimsel düşüncenin gelişmesi ve ilköğretim yıllarında, fen derslerine karşı olumlu davranışlar göstermelerinde öğretmenler anahtar rol oynamaktadır (Thulin ve Redfors, 2017). Meraklı, enerjik, hevesli, motive, risk alan, imkânsızı düşünen ve yapan yaratıcı çocuklar denemeler yaparlar ve bu denemeler sonucu hatalarıla öğrenirler, öğretmenler bu dönemde yol gösterici olarak çocukların ilgilerini canlı tutmalı ve iyi bir model olmalıdır (Devellis, 2012). Bu nedenle fen ögretiminde öğretmenin farklı yollar deneyerek uyum ve uyarlama becerisi geliştirmesi gerekmektedir. Ayrıca belirlenen kazanımların çocuklara kazandırılıp kazandırılmadığını da değerlendirerek, fen etkinlikleri planlarken gerekli değişiklikleri yapmalıdır (Güvenir, 2018). Kısacası ortam ve şartlar ne olursa olsun öğretmen, bir eğitim ortamının temel taşını oluşturmaktadır. Öğretmenlerin fen çalışmaları ile ilgili bilgi düzeyleri, görüşleri, tutumları, kendini yeterli ya da yetersiz hissetmeleri, daha önceki öğrenim sürecinde yaşadığ1 olumsuzlukların olup olmaması fen çalışmalarına karşı tutumları açısından çok önemlidir. Öğretmenin; vereceği eğitim hakkında bilgi sahibi olması, deneylere ve alternatif düşüncelere önem vermesi ve fen öğretiminin temelini çocuklara kazandırması beklenmektedir. Bu sebeple özellikle okul öncesi dönemde öğretmenlerin fen öğretimi konusundaki yeterlilikleri, üzerinde durulmasi gereken bir durumdur.

Öğretmen yeterliklerini ulusal ve uluslararası alan yazında temsil eden bir bileşen olarak kavramsallaştırılan $\mathrm{PAB}$, öğretmenlerde bulunması gerekli olan önemli bir bilgi türü olarak görülmektedir (Jones ve Moreland, 2005). Öğretimde temel oluşturan faktörlerin neler olması gerektiğine yönelik yapılmış olan araştırmalarda öğretmenin ne tür bilgiye sahip olduğu ve olması gerektiğine ilişkin önemli sonuçlara rastlanmaktadır. Fakat ulusal ve uluslararası çalışmalara bakıldığında; etkili öğretimin gerçekleşebilmesi için okul öncesi öğretmenlerinde var olması gereken öğretim yeterliliğine PAB'larına ilişkin hiç çalışma olmadığı görülmüştür. Oysa ki PAB çocuğun gelişimini etkileyen öğretmen yeterliliğinin anahtar bileşenidir (Kleickmann ve diğerleri, 2013). Aynı zamanda okul öncesi öğretmenlerinin konu alanına yönelik kavramlarını sınıf uygulamalarına yansıtma şekilleri de PAB'ları ile ilgilidir (De Jong, 
2003). Özellikle çocukların ilk öğretmenleri olan okul öncesi öğretmenlerinin değişen dünyaya uyum sağlayabilmesi için çocukların öğrenmesi ve gelişimine yönelik bilgiye, alan bilgisi ve programın amaçlarına yönelik bilgiye ve öğretim bilgisine sahip olması beklenmektedir (Darling-Hammond ve Baratz-Snowden, 2005). Bu nedenle özellikle okul öncesi öğretmenlerin PAB'ları, üzerinde durulması ve önem verilmesi gereken bir konudur.

Günümüzde PAB'ın hangi bileşenleri içerdiği ve bu bileşenlerin birbiri ile etkileşimi hakkındaki çalışmalar devam etmekte olup ögretmen adaylarının, ögretmenliğe yeni başlayan ögretmenlerin, deneyimli ögretmenlerin, araştırma görevlilerinin ve öğretim görevlilerinin sahip oldukları PAB'larla ilgili çalışmalar yapılmaktadır (Abell, Rogers, Hanuscin, Lee ve Gagnon, 2009). Okul öncesi bağlamında ise fen öğretim sürecindeki öğretmen PAB'larına yönelik herhangi bir araştırma literatürde yer almamaktadır. Bu nedenle özellikle okul öncesi öğretmenlerinin seçtiği konu alanı özelinde fen öğretimini nasıl gerçekleştirdiğini incelemek PAB alanında yeni sayılabilecek türden çalışmalardır. Farklı bir çalışma olmasının yanında bu çalışmada okul öncesi öğretmenlerinin akademik anlamda kendilerini geliştirmelerine teşvik etmesi ve eksiklikleri fark edebilmeleri amaçlanmıştır.

\section{Araştırmanın modeli}

Bir okul öncesi öğretmeninin fen öğretimine yönelik pedagojik alan bilgisinin keşfedilmesi amaçlanan bu çalışmada, nitel araştırma yaklaşımlarından biri olan durum çalışması yöntemi kullanılmıştır. Durum çalışması; araştırmacı veya uzman kişi tarafından yapılan görüşme ya da gözlemleri içeren nitel araştırma yöntemi içerisinde toplanan nitel veriler, yaşanılanların ve sahip olunan duyguların tüm gerçekliğiyle dışavurumunun ve neden olduklarını kapsayan veriler bütününü temsil etmektedir (Yıldırım ve Şimşek, 2013). Bu araştırmada incelenen durum; yüksek lisans öğrenimi devam etmekte olan bir okul öncesi öğretmeninin fen öğretimine yönelik pedagojik alan bilgisinin incelenip yeterliliğinin ne düzeyde olduğunu keşfetmek ile sınırlı olduğundan çalışmanın deseni tek durum çalışması (single case study) olarak belirlenmiştir.

\section{Çalışma grubu}

Bu çalışmada katılımcı grubu belirlemek için amaçlı örnekleme yönteminden faydalanılmıştır. Amaçlı örneklemede, belirli bir amaç doğrultusunda örnekleme dahil edilebilecek tipik durumlar araştırmacı tarafından belirlenmekte ve araştırmanın ihtiyaçları doğrultusunda örneklem oluşturulmaktadır (Leedy ve Ormrod, 2001). Amaçlı örnekleme yöntemlerinden biri olan ölçüt örneklemede ise; araştırmanın amacına uygun bir şekilde evreni yansitabilecek bir örneklemden seçilen, önceden belirlenmiş bir ölçütü karşılayan durumlar ile çalışılmaktadır. Belirlenen ölçüt veya ölçütler araştırmacı tarafından oluşturulabilmekte veya önceden hazırlanmış bir ölçüt listesi kullanılabilmektedir (Fraenkel ve Wallen, 2006). Bu araştırmada çalışma grubundaki öğretmeni belirlemek için amaçlı örnekleme yöntemlerinden biri olan ölçüt örnekleme yöntemi kullanılmıştır.

$\mathrm{Bu}$ araştırmanın çalışma grubunun belirlenmesinde MEB 2023 Eğitim Vizyonu'nda yer alan öğretmenlerin mesleki gelişiminin lisansüstü düzeyde desteklenmesi gerektiğine dair ibare göz önünde bulundurulmuş bu sebeple katılımcının yüksek lisans öğrenimine devam ediyor olması ve MEB programına bağlı kalarak bağımsız devlet anaokulunda en az 5 yıl deneyime sahip olması ölçüt olarak belirlenmiş. Bu nedenle fen öğretimine yönelik PAB düzeyini keşfedebilmek için yüksek lisans öğrenimi devam etmekte olan ve devlet anaokulunda görev yapan bir kadın okul öncesi öğretmeniyle çalışmaya karar verilmiştir. Bu amaç doğrultusunda gerekli izinler alındıktan sonra veriler toplanmaya başlamıştır. Patton (2014), nitel araştırmalarda araştırmacılara, katılımcıların kimliklerini korumak adına, çalışmayı yaptıkları yeri gizlemeleri ve katılımcıların isimlerini değiştirerek takma ad kullanmalarını tavsiye etmektedir. Bu uygulama katılımcı gizliliğinin her zaman korunması gerektiği varsayımına dayanmaktadır. Bu sebeple araştırmada, çalışma grubundaki yüksek lisans öğrenimi devam etmekte olan okul öncesi öğretmeninin kimliğini gizli tutmak amacıyla öğretmen için takma 
isim kullanılmıştır. Ayrıca çalışmanın yürütüldüğü devlet okulunun ismi de gizli tutulmuştur. Katılımcı öğretmene dair detaylı bilgiler aşağıda verilmiştir.

Gözde öğretmen, 30 yaşında ve bir çocuk annesidir. Öğrencilik hayatı boyunca hep öğretmen hayali olan Gözde öğretmen, düz liseden mezun olduktan sonra bir devlet üniversitesinde dört yıl boyunca okul öncesi öğretmenliği bölümünde okumuş lisans mezunudur. Lisans öğrenimi süresince okul öncesi öğretmenliği bölümüne dair pek çok ders görmüş olan Gözde öğretmen bu dersler içinde yalnızca bir dönem okul öncesinde fen eğitimi dersi almış onun dışında fen öğrenimine dair hiçbir çalışmada yer almamış ve hizmet içi eğitim veya seminere katılmamıştır. Şu an aktif olarak yine aynı anabilim dalında yüksek lisans öğrenimini sürdürmektedir. Aynı zamanda 6 yıldır bir devlet anaokulunda kadrolu öğretmen olarak görev almaktadır. Altı yıl süresince iki yıl ücretli öğretmenlik yaptığı kurumda dört yıl ise atanmış olduğu zorunlu görev yeri olan Esenyurt'ta bir bağımsız devlet anaokulunda görevini yapmaktadır. Çalışmanın yürütüldüğü 2019-2020 eğitim-öğretim yılında Gözde öğretmenin okulunda altı okul öncesi öğretmeni görev almakta ve 120 çocuk bulunmaktadır. Uygulamanın yapıldığı sınıfta 48 ay grubu, 20 çocuk vardır. Sınıf içerisindeki fiziki durum incelendiğinde sınıfın geniş olduğu, çocukların rahatlıkla hareket edebileceği alanlar var olmasına rağmen sınıf içerisinde çok fazla materyalin bulunmaması, farklı merkezlere yer verilmediği görülmüştür. Özellikle sınıf içerisinde fen etkinliklerine dair hiçbir materyale rastlanmamış olması ve materyal eksikliği nedeni sorulduğunda ise okulun materyal alma konusuna sıcak bakmadığı aynı zamanda velilerin de ekonomik olarak zorluk yaşadıklarını dile getiren Gözde öğretmen, bu nedenle sınıfında çok fazla fen etkinlikleri uygulayamadı̆̆ını dile getirmiştir.

\section{Veri toplama araçları}

Nitel araştırmalarda güvenirlik ve geçerlilik sağlamada kullanılan önemli stratejilerden biri, çeşitlemedir. Çeşitleme (triangulation) farklı veri kaynakları, veri toplama ve analiz yöntemleri ile araştırmanın seyrine etki ederek inandırıcılı̆̆ 1 arttırmak için yapılır (Flick, 2018). Araştırmaya katılım gösteren yüksek lisans öğrenimi devam etmekte olan okul öncesi öğretmenin pedagojik alan bilgi düzeyinin derinlemesine betimlenebilmesi için üç farklı veri toplama aracından yararlanılarak veri çeşitlemesi sağlanmıştır. Bu veri toplama araçları; Öğretim Etkinliği Ders Planı oluşturma, PAB Görüşme Soruları ve Gözlem şeklindedir. Veri toplama araçlarının oluşturulması, kullanımı ve analizi, aşağıda detaylı olarak açıklanmıştır.

\section{Ö̆̆retim etkinliği ders planı}

Ders planları, öğretmenlerin bir konuya ilişkin kavramsal anlama düzeyleri hakkında önemli ipuçları sağlamaktadır (Thomas ve Magilvy, 2011). Nitekim ulusal ve uluslararası PAB çalışmalarında; öğretmenlerin pedagojik alan bilgilerini belirlemek için ders planı hazırlamaları istenmiş ve bunları veri toplama aracı olarak kullanmışlardır (Faikhamta, Coll ve Roadangka, 2009). Loughran ve diğerleri, (2006) fen bilgisi öğretmenlerinin PAB'larını belirli bir konu için yakalamak ve canlandırmak amacıyla Öğretim Etkinliği Ders Planı (CoRe) geliştirmiştir. Kısaca, bir CoRe, pedagojik taleplere karşı haritalanan herhangi bir konu için 'büyük fikirlerin' tanınmasına dayanan detaylı bir fen öğretimi içeriğini yansıtır. Dolayısıyla, CoRe öğretmenlerin belirli bir bilim kavramı/konuyu öğretme bilgisini ortaya çıkarmak için tasarlanmıştır. Bu çalışmada da yüksek lisans öğrenimi devam etmekte olan okul öncesi öğretmenine ait PAB'1 ortaya çıkarmada yardımcı olacağı düşünüldüğünden öğretim etkinliği ders planı kullanılmıştır. PAB'ın beş bileşeni gözetilerek düzenlenmiş olan öğretim etkinliği ders planında toplam altı soru bulunmakta bu soruların ilki genel öğretime yönelik olarak diğer beş soru PAB bileşenleri ile ilişkilendirilerek düzenlenmiştir $(E K-1)$. Ders planında yer alan ifadeler, uzman yardımı ve önerileriyle okul öncesi bağlamına uyarlanmış ve öğretmenlerin görüşlerini yansıtmalarında yardımcı olabilecek biçimde metin üzerinde zenginleştirmeler yapılarak kullanılmıştır.

Aşağıda ise araştırmaya katılan öğretmenin yaklaşık (30-40) dakika aralığında oluşturmuş olduğu öğretim etkinliği ders planında ele aldığı fen öğretimi konu alanı, kazandırmayı hedeflediği kazanım-göstergeler ve bilimsel süreç becerileri aynı zamanda ders 
planı uygulamalarını gerçekleştireceği çocukların ay bazlı yaş grubunu içeren Tablo 1 bulunmaktadir.

Tablo 1.

Katılımcı Öğretmenin Fen Öğretim Etkinliğinin Karakteristiği

\begin{tabular}{|c|c|c|c|c|}
\hline Öğretmen & Konu Alanı & Kazanım ve göstergeler & $\begin{array}{l}\text { Bilimsel süreç } \\
\text { becerileri }\end{array}$ & $\begin{array}{l}\text { Grubun } \\
\text { düzeyi }\end{array}$ \\
\hline Gözde & $\begin{array}{l}\text { Farkl111klar1 } \\
\text { fark etme/ayırt } \\
\text { etme }\end{array}$ & $\begin{array}{l}\text { Benzerlik ve farklılıkları ayırt } \\
\text { eder. } \\
\text { Sorulan soruları cevaplar kendisi } \\
\text { soru sorar. }\end{array}$ & $\begin{array}{l}\text { Gözlem, dikkat, } \\
\text { ayirt etme, } \\
\text { k1yaslama }\end{array}$ & 48 ay \\
\hline
\end{tabular}

Araştırmaya katılan Gözde öğretmenin fen öğretim etkinliği karakteristiğini incelediğimizde; farklılıkları fark etme/ayırt etme konusunu ele aldığı ve sınıfındaki 48 ay çocuklarına; benzerlik ve farklılıkları ayırt eder, sorulan soruları cevaplar kendisi soru sorar gibi kazanımlarını kazandırmayı ve bununla birlikte gözlem, dikkat, ayırt etme, kıyaslama gibi bilimsel süreç becerilerini desteklemeyi hedeflediği görülmektedir.

\section{Pedagojik alan bilgisi görüşsme sorulart}

Yüksek lisans öğrenimine devam etmekte olan bir okul öncesi öğretmeninin fen öğretimine yönelik PAB'ını keşfetmek amaciyla öncelikle Magnusson, Krajcik ve Borko'nun (1999) bahsettiği $\mathrm{PAB}$ bileşenleri Türkçeye çevrilmiş, fen eğitimi alanından 2 uzmanın görüşlerine başvurulmuş iç geçerlilik ve dış denetim sağlanmıştır sonrasında beş PAB bileşeni okul öncesi bağlamında düzenlenmiş ve okul öncesi öğretmenliği alanından bir uzman görüşüne başvurularak hazırlanmış görüşme formunda; fen öğretimi için öğretime yönlendirme, öğrenci anlayışları bilgisi, ölçme ve değerlendirme bilgisi, öğretim stratejileri bilgisi ve müfredat bilgisi boyutlarında sorular hazırlanmıştır PAB görüşme formunda araştırmaya katılan öğretmen ilk aşamada iki farklı giriş sorusunu yanıtlamış ve sonrasında öğretime yönlendirme, öğrenci anlayışları bilgisi, müfredat bilgisi, öğretim stratejileri bilgisi, ölçme ve değerlendirme bilgisi temelinde beş farklı PAB bileşenine yönelik sondaj sorularından oluşan 15 soruya yanıt vermiştir $(E K-2)$. Görüşme öğretmenin müsaitlik durumuna ve sorulara verdiği cevaplara bağlı olarak (40-60) dakika aralığında sürmüş ve araştırmacı tarafından gerçekleştirilmiştir.

\section{Gözlem rubriği}

Gözlem, bir mekânda veya kuruluşta olan durumu detaylı olarak belirlemek hedefiyle kullanılan bir yöntemdir. Gözlem tekniğinin en güçlü yönü, çevrede olan tüm olayların doğal bir şekilde ele alınarak verilerin toplanmasına olanak sağlamasıdır. Baxter ve Lederman'ın (1999) belirttiği gibi, gözlemler bir öğretmenin PAB'ına yalnızca sınırlı bir bakış açısı sağlayabilir, çünkü bu kısmen bir içyapıdır, bu yüzden öğretmenlerden PAB'larını ifade etmeleri istenir. Çünkü PAB karmaşık bir kavram olduğu için okul öncesi öğretmenleri çoğu zaman PAB kavramlarını içeren bir dil kullanmazlar ve dolayısıyla öğretim uygulamalarına dair bilgilerinin çoğu gizlidir (Korthagen ve Kessels, 1999). Araştırmaya dâhil olan yüksek lisans öğrenimi devam etmekte olan okul öncesi öğretmeninin PAB'ına dair daha somut ve takip edilebilir bilgiler elde edebilmek için sınıf içi gözlemler yapılmıştır. Bu sayede öğretmenin bilgiyi eyleme dönüştürme süreçlerinin ve öğrettikleri bağlamın daha iyi anlaşılması amaçlanmıştır. Sınıf içi gözlemler, Newton, Driver ve Osborne (1999) tarafından geliştirilen gözlem protokolü yardımıyla yapılmıştır. Bu protokole göre sınıf içi gözlemler genel olarak üç temel çerçeveye bağlı kalınarak yapılır. Bunlar; ögrencilerin dâhil oldukları aktiviteler, (PA) aktiviteler sırasında nasıl gruplandırıldıkları $(P W G)$ ve ögretmen-ögrenci etkileşim biçimleri (P\&TI) şeklindedir. Burada belirtilen amaçlar doğrultusunda, öğretmen ve öğrencilerin derslerin hangi anında (birer dakikalık zaman aralıklarıyla) neler yaptıkları belirlenmiştir. Gözlem sürecinde katılımcı öğretmenin tüm davranışlarını rahatlıkla görülebileceği şekilde kamera uygun bir yere 
yerleştirilmiştir. Araştırmacı, bir çocuk gibi belirli bir yerde derse müdahale etmeden öğretim sürecini gözlemlemiş ve süreçte önemli gördüğü kısımları not etmiştir. Bu şekilde, hem görüşme protokolü aracılı̆̆ıyla ulaşılan öğretmen PAB'ının pratik hali hem de okul öncesi öğretmenlerinin fen etkinliklerini uygularken sınıflarında nasıl davrandıklarının detayları ortaya çıkarılmıştır. Analiz sonucunda elde edilen veriler gözlem rubriğine kayıt edilmiş ve sonrasında gözlem kayıtları yorumlanmıştır.

\section{Verilerin Toplanması ve Analizi}

Nitel araştırmalarda veri toplama ve analiz etme bütünsel ve eş zamanlı olarak devam eden ve araştırmacılar için zorlu bir süreçtir (Yin, 2017). Merriam (1998) veri analizinin karmaşık bir süreç olduğunu ve verilerle bulgular arasında sürekli gidip gelinen ve tümevarım-tümdengelim yaklaşımları arasında süren bir prosedür olduğunu belirtmektedir. Bu çalışmada, Strauss ve Corbin'in (1990) önerdiği şekilde belirgin olan temaların yanı sıra belirgin olmayan temaların da ortaya çıkarılabilmesi amacıyla içerik analizi yaklaşımı benimsenmiştir. Katılımcının öğretim etkinliği ders planı ve PAB görüşme sorularına verdiği yanıtlar, tümevarımsal içerik analizi yöntemi ile analiz edilmiştir. Tümevarımsal içerik analizi, Yıldırım ve Şimşek'in (2013) öne sürdügü aşamalar halinde gerçekleştirilmiştir. İlk aşama olan verilerin kodlanması sürecinde elde edilen ham veriler, anlamlı bölümlere ayrılmış ve her bölümün kavramsal olarak ne anlam ifade ettiği saptanmıştır. İkinci aşama olan temaların bulunması sürecinde ise önceki aşamada elde edilen kodlamalar arasındaki ortak yönler bulunmuş kavramsal kategoriler haline getirilmişlerdir. Bunun ardından elde edilen kod ve temalar, kodların ve temaların düzenlenmesi aşamasına bağlı kalınarak işlenmiş bir hale getirilmişlerdir. Sonrasında Sürekli Karşılaştırma Yöntemi (Glaser ve Strauss, 1967) ile katılımcının öğretim etkinliği ders planı sorularına ve PAB görüşme sorularına verdiği yanıtlar, araştırmanın amacı doğrultusunda karşılaştırmalı olarak derinlemesine incelenmiş, içerisinde analitik değerlendirme seçeneklerinin bulunduğu Kodlama Anahtarı oluşturulmuştur. Veri analizinin son aşamasında katılımcı öğretmenden oluşturmuş olduğu ders planını uygulaması istenmiş ve uygulama sürecinde elde edilen veriler gözlem rubriğine kaydedilmiştir. Gözlem rubriğinden elde edilen veriler sonucunda öğretmenin ders planı sorularına ve PAB görüşme sorularına verdiği yanıtlar karşılaştırılmış ve yüksek lisans öğrenimi devam etmekte olan okul öncesi öğretmeninin fen öğretimine yönelik pedagojik alan bilgi düzeyi hakkında bulgulara ulaşılmış aynı zamanda öğretmenin PAB bileşenleri arasındaki bağlantısının ne düzeyde olduğu da tespit edilmiştir. Bu sayede hangi bileşenlerin birbiriyle daha sıkı bir ilişki içerisinde olduğu, PAB haritası içerisinde belirtilmiştir.

\section{Geçerlik ve Güvenirlik}

$\mathrm{Bu}$ çalışma nitel bir çalışmadır. Nicel çalışmalarda olduğu gibi geçerlik ve güvenirliğin sağlanması için yapılması gereken bazı ölçütler vardır. Merriam'a (1998) göre araştırmacı, çalışmanın güvenirlik ve geçerliğini, çalışma sürecinde ve verilerin analizinde dikkate almalıdır. Lincoln ve Guba, (1985) nitel araştırma süreçlerinde geçerlik ve güvenirlik ölçütlerini yerine getirebilmek adına inandırıcılık, aktarılabilirlik, tutarlık ve onaylanabilirlik kavramlarını kullanmışlardır. $\mathrm{Bu}$ araştırma sürecinde nitel verilerin analizi aracılığıyla ulaşılan sonuçların inandırıcılığını sağlamak için Lincoln ve Guba'nın (1985) önerdiği stratejiler uygulanmıştır. Araştırmacı, öncelikle uzun süreli etkileşim sağlamak amacıyla iki hafta boyunca katılımcı öğretmen ile dörder saat görüşerek toplamda sekiz saat süren uygulama-veri toplama sürecinin her aşamasında etkin bir şekilde yürütücü görevi görmüştür. Araştırmacı, çalışmada katılımcı ögretmenden üç farklı veri toplama aracıyla verilerini toplayarak veri çeşitlemesi yapmış ve güvenirliği sağlamak amacıyla kullanıldığı ders planı oluşturma ve PAB'a yönelik görüşme sorularının Türkçeye uyarlanmasında ve geliştirilmesinde iki uzmanın görüşüne başvurmuştur. Araştırmacı aynı zamanda aktarlabilirlik ölçütünü yerine getirmek için Erlandson, Harris, Skipper ve Allen (1993) tarafından önerilen iki yöntem uygulamışır. Bunlardan biri ayrıntılı betimlemedir. Araştırmacı; bu çalışmanın katılımcı grubunu, kullandığı veri toplama araçlarını veri analiz yöntemlerini, örnekleme yöntemlerini ve araştırmanın önemi/rasyoneli gibi hususları ayrıntılı bir şekilde açıklamıştır. Diğer yöntem ise amaçlı örneklemedir. Araştırmacı, araştırma 
sürecine dâhil ettiği katılımcıyı, amaçlı örnekleme yöntemini kullanarak belirlemiştir. Aynı zamanda geçerlik ve güvenirliği sağlamak için kullanılan bir diğer ölçüt ise tutarlık'tır. Bu araştırmada tutarlığ sağlamak için veri toplama araçlarının oluşturulması, pilot ve asıl uygulamaların yapılması ve veri analizi süreçlerinde uzman görüşlerine başvurulmuştur. Son olarak onaylanabilirlik ölçütünü yerine getirmek için ise katılımcının oluşturduğu ders planına ve PAB'a yönelik görüşme sorularına verdikleri yanıtlardan "doğrudan alıntılar"a yer vermiştir. Değişik kaynaklardan verilerin toplanması, çalışmanın uzun zamana yayılması ve farklı uzmanların onayına sunulması yoluyla bu araştırmada veri üçgenleme yöntemi yapılarak güvenirlik sağlanmıştır.

\section{Bulgular}

$\mathrm{Bu}$ bölümde yüksek lisans öğrenimi devam etmekte olan bir okul öncesi öğretmeninin oluşturduğu ders planı, PAB bileşenleri sorularına verdiği yanıtlar ve sınıf içi öğretimine dair gözlemlerin analizinden elde edilen bulgular sunulmuştur. İlk olarak katılımcı öğretmenin ders planı ve görüşme sorularına verdiği yanıtlar üzerinde gerçekleştirilen tümevarımsal içerik analizi sonuçlarına yer verilmiştir. Gözde öğretmenin atıfta bulunduğu temaları ve kavramsallaştırmaları EK-3 yardımıyla sunulmuştur. Ayrıca Şekil 1'de Gözde öğretmenin PAB haritası oluşturulmuş ve yorumlanmıştır.

\section{Gözde Öğretmenin Öğretimsel Yetkinliği}

Okul öncesi dönemde fen öğretimine yönelik öğretimsel yetkinliği tespit etmek amaciyla sürecin başında katılımcı öğretmene, öğretim etkinliği ders planı ve okul öncesi dönemde fen öğretimine yönelik PAB görüşme soruları yöneltilmiştir. Gözde öğretmenin sorulan sorulara verdiği yanıtlara bakıldığında; çocuk merkezli yaklaşımı önemsemesi çocukların duyuşsal alan gelişimlerine atıfta bulunmasına rağmen öğretimsel süreçte ögretmen merkezli süreçlere atıfta bulunduğu görülmüştür.

Gözde öğretmenin kavramsallaştırmalarını detaylandırıldığında; lisans ve yüksek lisans süreci boyunca fen öğretimi dersine gerekli önemin verilmediğini bu nedenle kendini fen öğretimi konusunda yetersiz gördüğünü bunun yanında müfredat konusundaki yetersizlikleri de dile getirerek müfredat bilgisine atıfta bulunduğu tespit edilmiştir.

Genel anlamda fen ögretimi konusunda kendimi yeterli bulmuyorum tabi ki. Materyallerimiz de çok az yani sadece benden kaynakl değil. Materyalleri temin etmekte zorlaniyorsun. Ve ayrıca fen öğretimiyle ilgili lisans sürecinde çok da iyi bir eğitim almadık. Daha çok gelişimsel eğitimlerde iyi olduğumuzu düşünüyorum (PAB görüşme soruları).

Fen öğretimi sürecinde çocuklarda motivasyonu arttırmanın ve merak uyandırmanın önemine değinen Gözde öğretmen, öğretim öncesi ve süreci boyunca materyal yetersizliğinin üzerinde durmuştur. Aynı zamanda Gözde öğretmenin, çoğunlukla öğretmen merkezli süreçlere atıfta bulunmasına karşın çocukların duyuşsal alan gelişimlerini önemsediğini de belirtmiştir. $\mathrm{Bu}$ nedenle, Gözde öğretmenin sorulara verdiği yanıtlarının çeliştiği tespit edilmiştir.

\section{Gözde Öğretmenin PAB Düzeyinin Belirlenmesi}

Araştırmaya dâhil olan öğretmenin okul öncesinde fen öğretimine yönelik PAB görüşme soruları ve oluşturduğu öğretim etkinliği ders planı soruları her bir PAB bileşeni özelinde ayrı alt başlıklar halinde sunulmuştur.

\section{Öğretime yönlendirme}

Katılımcı öğretmenin, seçtiği konu alanı özelinde çocukları fen öğretimine dahil etmeye yönelik öğretimsel amaçları hakkında pek çok bulguya ulaşılmıştır. Genel olarak baktığımızda Gözde öğretmenin bilginin aktarılması ve günlük yaşama tranfer edilmesini hedeflediği, genel olarak müfredat bilgisine sahip olduğu fakat bildikleri ile yapmayı planladıkları arasında çelişkili 
yanıtlar verdiği ve aynı zamanda çoğunlukla öğretmen merkezli süreçlere atıfta bulunduğu görülmektedir. Detaylandıracak olursak;

Çocukların farklı yani uzun ya da kısa oluşu ya da kıvırcık oluşu sinıfta problem olabiliyor. Saçını toplamış olsa bile bazen çocukları çok rahatsız ediyor. (PAB görüşme soruları). Bazısında bizde farklı olan bir şeyi özel olduğunu anlatmaya çalıştım. Bunu da ancak deney ile anlatabileceğimi düşündüm o yüzden deneyimi seçtim (Öğretim etkinliği ders planı sorularl).

Günlük yaşamda ve sınıf ortamında yaşanan farklı durumların çocuklar üzerinde çok büyük etkilere yol açtı̆̆ını belirten bu sebeple çocukların farklılıkları fark etmesi, farklılıkları kabullenmelerini ve olumlu benlik algısı geliştirebilmelerini öğretimsel olarak amaç edinen Gözde öğretmen, çocukların kazanımları kazandırmaktan çok bilgiye ulaşmalarını ve bilgiyi günlük hayatlarında kullanabilmeleri gerektiği üzerinde durmuştur. Gözde öğretmenin, farklı1ıklara karşı farkındalık oluşturmaya ve bilginin aktarılmasına yönelik atıfta bulunurken bu konuyu yalnızca sözel ifadelere yer vererek, öğretim sürecinde aktif rol oynayarak deney yöntemine başvurması nedeniyle öğretmen merkezli süreçlere atıf yaptığı tespit edilmiştir.

\section{Öğrenci anlayışları bilgisi}

Gözde öğretmenin, seçtiği konu alanına yönelik çocukların öğrenme gereksinimleri ve öğrenme güçlüğü çektiği durumlara ilişkin sahip oldukları bilgileri içeren bu PAB bileşeninde katılımcının genel olarak, bilişsel olgunluğa ulaşmaya atıfta bulunduğu ve geleneksel yaklaşımlara başvurduğu söylenebilir. Detaylandıracak olursak;

Soru sorabilmesi mesela bă̆lantı kurması ögrenmesi için bence bunlar önemlidir. Kiyaslama yapabilmesi lazım. Ilgi de duyması lazım o etkinliğe bunu da ancak çocuklara sorular sorarak anlayabilirim (PAB görüşme sorularl).

Çocuğun nitelikli öğrenmeler gerçekleştirebilmesi için bilişsel anlamda yeterli olgunluğa ulaşmaya ihtiyacı olduğunu söyleyen ve çocuklardaki hazırbulunuşluk düzeyinin öneminden bahseden Gözde öğretmen bunların yanında çocukların konu ile ilgili merak duygusunu güdüleyerek soru sormalarının teşvik edilmesi gerektiğini ve aynı zamanda çocuklara sorular yönelterek geleneksel yöntemlere başvurup değerlendirmeler yapabileceğini dile getirmiştir.

\section{Müfredat bilgisi}

Bu bileşen, katılımcı öğretmenin seçtiği konu alanı özelinde müfredat hakkındaki öğretmen bilgisini temsil etmektedir. Araştırmaya dâhil olan öğretmenin müfredat hakkında genel bilgisinin var olduğu, müfredatın belirlenen kazanım göstergeler açısından yeterli olduğu ve öğretmenlere yol gösterdiğini dile getirerek; müfredat yetkinliğine, kazanım odaklı yönelimlere atıfta bulunduğu görülmüştür.

Yani kazanımlara yer verilmiş. Soru sorma verilen soruları cevaplama, aynı ve farklı olanları ayırt etme gibi kazanımlara yer verilmiş. Daha fazla vardı da hatırlayamadım şimdi. Ama müfredatta fen öğretimini nasıl gerçekleştireceğime iliş̧kin yönergeler yok (Öğretim etkinliği ders planı soruları). Güncellenen yeni programda eskiye göre daha da fazla kazanım gösterge var daha iyi oluyor. Okulda uyguladı̆̆ımız etkinliklerde daha fazla kazanım kazandırmış oluyoruz (PAB görüşme sorularl).

Görüldüğü üzere Gözde öğretmen müfredatta seçtiği konu alanı özelinde yeterli kazanıma yer verildiğini dile getirmiş ancak bu kazanımları örneklendirilmesi beklediğinde kazanım göstergeleri tam hatıllayamadığını önünde müfredata yönelik kazanım gösterge listesinin bulunmadığından bahsetmiştir. Müfredatın öğretmenlere rehber olması açısından 
öğretimin nasıl gerçekleşeceğine dair yönlendirmelerin olmadığııı dile getiren Gözde öğretmen yine de güncellenen programın eski programla karşılaştırmasını yaparak etkinliklerinde geçmişe nazaran daha fazla kazanımı ele alarak çocuklara kazandırabildiğini belirtmiş, müfredat yetkinliğine ve kazanım odaklı yönelimlere atıfta bulunmuşstur.

\section{Öğretim stratejileri bilgisi}

Öğretmenlerin öğretim stratejileri ve temsil bilgilerinden yararlanma şeklini gösteren bu bileşende iki önemli bulgudan söz edilebilir. Bunlardan ilki, Gözde öğretmenin öğretim öncesinde çocukların iç motivasyonunun yüksek olması merak duygularının tekiklenmesi gerektiği üzerinde özellikle durmuş olması, bir diğer bulgu ise söylediğinin aksine çoğunlukla geleneksel strateji yöntemlerine atıfta bulunmasıdır. Elde edilen bulgulara bakıldığında Gözde öğretmenin sorulara verdiği yanıtlarda kendisi ile çeliştiği görülmektedir.

Merak uyandırmıştım. Malzemeleri çıkarmıştım. Direk şunu yapıyorum dememiştim. Önce malzemeleri göstermiştim. Ne yapabiliriz gibi. Daha çok merak uyandırırız. Zaten çok ilgilerini çekiyor (PAB görüşme soruları). Deney yapabilirim. Sonra ben sorular sordum çocuklar sorular sordu yani soru cevap yöntemi (Öğretim etkinliği ders planı sorulart).

Çocukları fen öğretimi öncesinde meraklarını tetikleyerek etkinliğe ilgi duymalarını sağlamayı hedefleyen Gözde öğretmen, öğretim sürecinde iç motivasyonu arttırmaya atıfta bulunmuştur. Aynı zamanda öğretim öncesinde seçtiği konu alanı özelinde çocuklara yapılandırılmış ve yarı yapılandırılmış sorular yönelterek sürece hazırlık yaptı̆̆ zaman zaman anlatma yöntemine başvurarak çocukları sürece hazırladığını belirtmiştir. Böylece Gözde öğretmenin geleneksel anlatım yöntemlerinden yararlanarak öğretmen merkezli süreçlere atıfta bulunduğu tespit edilmiştir.

\section{Ölçme ve değerlendirme bilgisi}

Bu bileşen, katılımcı öğretmenin seçtiği konu alanı özelinde sürecine dâhil etmeyi düşündüğü ölçme ve değerlendirme yaklaşımlarını temsil eder. Genel olarak Gözde öğretmenin ölçme ve değerlendirme bilgisi bileşenine yönelik sorulara verdiği yanıtlarda çocukları daha aktif kılmaktan ziyade çocukları yönlendirebildiği, yapılandırılmış sorularına cevaplar alarak süreci yönetmeyi planladığı görülmüştür. $\mathrm{Bu}$ nedenle Gözde öğretmenin geleneksel ölçme değerlendirme tekniklerine atıfta bulunduğu söylenebilir.

Genelde sordukları sorulardan, kurdukları bağlantılardan, kendi hayatlarından örnekler vermelerinden anliyorum. Kendileri sorular sordular ben sorular sordum. Soru cevap yöntemiyle anlarım (PAB görüşme sorularl).

Gözde öğretmenin verdiği yanıtları detaylandırdığımızda yukarıda da belirttiğimiz gibi geleneksel ölçme ve değerlendirme tekniklerinden yararlandığı ve öğretmen merkezli süreçlere atıfta bulunduğu tespit edilmiştir. Aynı zamanda bilginin kazanılması ve günlük hayata aktarılması üzerinde durmuş ve bilginin günlük yaşama transferine atıf yaptığını görülmüştür.

\section{Gözde Öğretmenin PAB Bileşenleri Arasındaki Etkileşim}

Araştırmaya katılan Gözde öğretmenin ele aldığı konu temelindeki PAB Haritası Tablo 3'te özetlenmiştir. Buna göre özetlenen PAB haritasında her bağlantının frekansı, bağlantının gücünü göstermektedir. PAB bileşenleri arasındaki etkileşim haritaları, karşılaştırmalı yöntem analizi kullanılarak yorumlanmıştır. Araştırmanın güvenirliliğini arttırarak veri toplama araçlarından elde edilen sonuçların desteklenmesine ve ortaya çıkan kalıpların analiz edilmesine katkıda bulunarak araştırmaya farklı bir boyut kazandırılmıştır. 

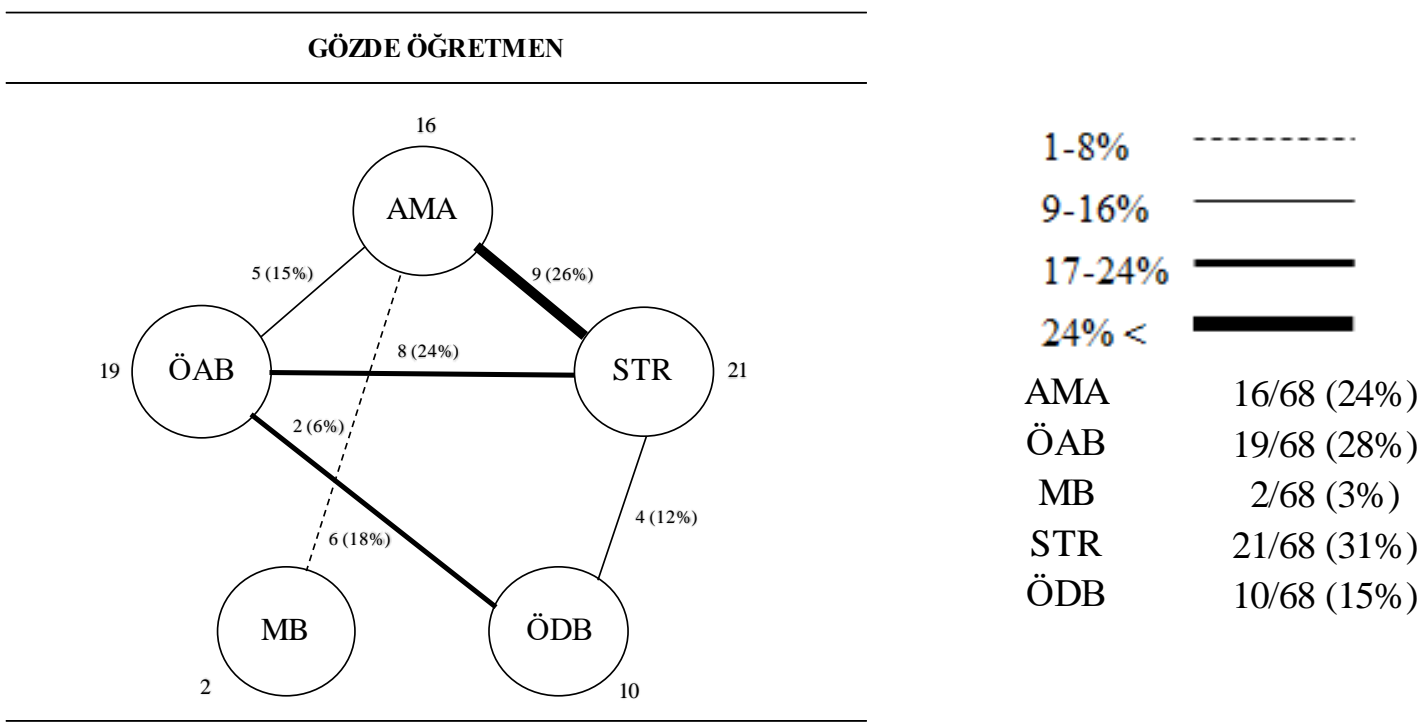

Şekil 1. Gözde öğretmenin PAB harita gösterimi

Gözde öğretmenin PAB haritasındaki bileşenler arasındaki etkileşime bakıldığında, bileşenler arasında toplamda 68 etkileşim kurduğu; Öğretime Yönlendirmede (AMA) en fazla Öğretim Stratejileri Bilgisi (STR) ile etkileşimde bulunduğu, Öğrenci Anlayışları Bilgisi (ÖAB) bileşenini pek çok bileşen ile desteklediği fakat Müfredat Bilgisi (MB) bileşeni ile hiç bağlantı kurmadığı görülmektedir. Gözde öğretmenin fen öğretim sürecinde Müfredat Bilgisi bileşenine etkileşiminin az olmasına karşın Öğretim Stratejileri Bilgisi ve Öğrenci Anlayışları Bilgisi bileşenlerine etkileşiminin yüksek olması öğretim sürecinde kendini yetersiz hissetmesine rağmen mümkün olduğunca çocuk merkezli bir süreci benimsemeye çalıştığı yorumlarını desteklenmektedir.

\section{Öğretimsel İçeriğin Pratik Değişimi}

Araştırmaya dâhil olan Gözde öğretmenin gerçekleştirdiği fen öğretimine dayalı sınıf içi öğretim uygulaması Aktivite Türü, (PA) Öğrenci ve Ögrretmen Etkileşimleri (P\&TI) ve Öğrenci Çalışma Grubu $(P W G)$ çerçevesi dahilinde aşağıda yer alan grafiğe göre yorumlanmıştır. Ayrıca Gözde öğretmenin sınıf içerisinde gerçekleştirdiği fen öğretimine dair gözlem notları da paylaşılmıştır.

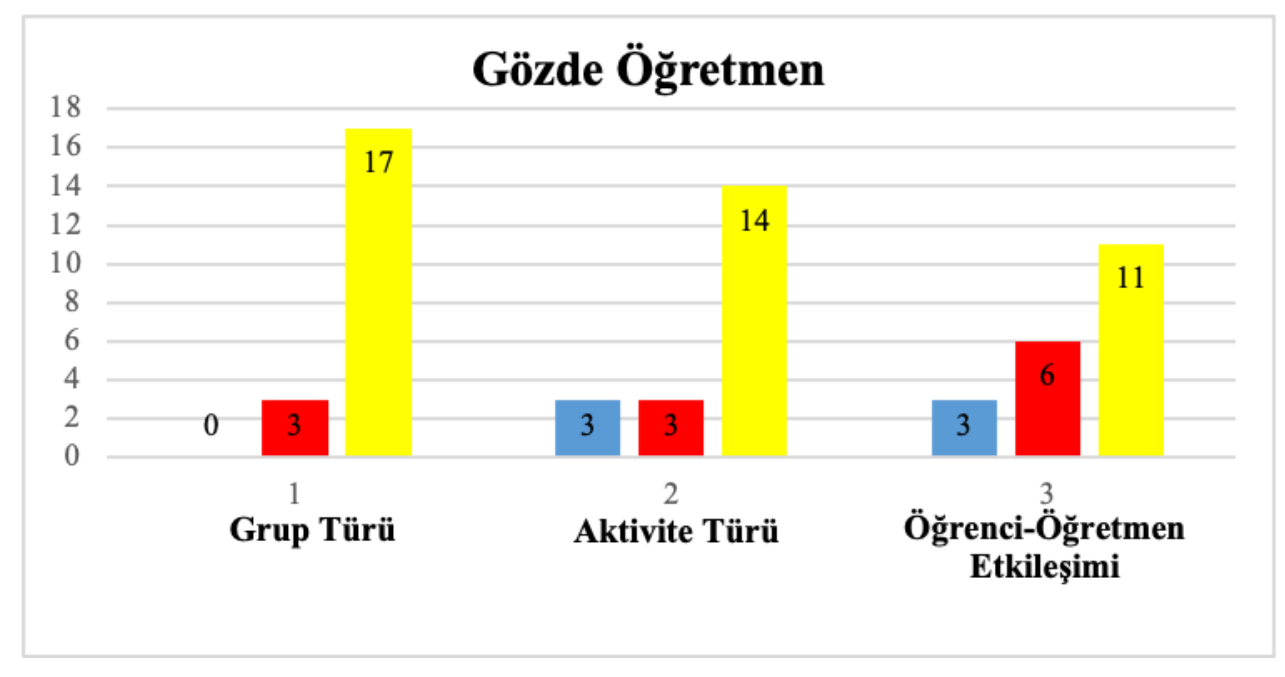

Grafik 1. Gözde öğretmenin sınıf içi gözlem grafiğgi 
Gözde öğretmenin seçtiği fen konusu özelinde sınıf içi öğretim uygulamana dair grafiğe bakıldığında çocukların meşgul olduğu ana faaliyet için sosyal ortam açısından $(P W G)$; çoğunlukla küçük grup etkinliğine başvurarak süreci yönettiği, aktivite türü $(P A)$ açısından baktığımızda; çocukları, küçük gruplar halinde öğretmenin dersi anlatması ve soru-cevap süreçlerine dâhil ettiği görülmektedir. Diğer yandan çocukların yalnızca gözlemci olarak katıldıkları, öğretim sürecinde çocukları pasif kılan bir etkileşim biçimi olan yapılandırılmış etkinlik ve gösteri gözlemi faaliyetleriyle öğretime başladığı görülmektedir. Örneğin seçtiğ konu alanı özelinde fen öğretimini gerçekleştiren Gözde öğretmen, çocuklara kullanacağ 1 materyaller hakkında yapılandırılmış sorular yönelterek öğretime başlamış, çocukların izleyici olduğu öğretmen merkezli bir yaklaşım ile deneyi uygulamış ara ara yapılandırılmış etkinlikler için çocuklara görevler vererek öğretim sürecine çocukları da katmaya çalışmıştır. Süreç sonunda ise çocukları genel anlamda söylem temelli diyalojik bir etkileşim biçimi olan Grup Tartışması faaliyetine dâhil etmiştir. Gözde öğretmenin sınıf içi öğretim uygulamalarına çocuklar ve öğretmenler arasındaki söylemsel etkileşimler ( $P \& T I)$ açısından bakıldığında ise Gözde öğretmenin ağırlıklı olarak soru-cevap etkileşimlerine odaklanmış olduğu yorumu yapılabilir.

\section{Gözlem notları}

Çocuklar masaya davet edilerek yerlerinde oturmaları beklendi. Çocuklar yerlerine geçtikten sonra bir masanın başına oturdu ve küçük bir gruba hitap ederek elinde bulunan materyallerin tek tek ne olduğu soruldu. Sonrasında deney uygulanmaya başlandı. Mürekkep öğretmen tarafından masada bulunan pamuğun üzerine döküldü Öğretmen pamuktaki mürekkebin içine bir parmağını batırarak önünde bulunan boş kağıt üzerine parmağının izini çıkararak bir büyüteç yardımı ile parmak izini nasıl incelediğini çocuklara gösterdi. Sırayla aynı işlemleri çocuklardan bireysel olarak yapmaları istendi. Çocuklar parmak izlerini inceleyip birbirlerinin parmak izlerindeki farklar üzerine sohbet ettiler bu sırada öğretmenin etkinlik hakkında sorduğu yapılandırılmış sorular çocuklar tarafından cevaplandı ve farklılıklar benzerlikler hakkında sohbet edildi. Etkinlik sonunda çocuklara evlerindeki tüm bireylerle bu etkinliği tekrarlayarak parmak izlerinin benzerlikleri ve farklılıkları hakkında konuşmaları istendi.

\section{Tartışma, Sonuç ve Öneriler}

$\mathrm{Bu}$ araştırmada Magnusson ve diğerlerinin (1999) fen öğretiminde PAB'a yönelik ileri sürdükleri 'öğretime yönlendirme, öğrenci anlayışları bilgisi, müfredat bilgisi, öğretim stratejileri bilgisi, ölçme ve değerlendirme bilgisi' bileşenlerinden yola çıkılarak okul öncesi dönem fen öğretiminde bir okul öncesi öğretmeninin PAB niteliği tanımlanmaya, keşfedilmeye çalışılmıştır. Çünkü ulusal ve uluslararası çalışmalar incelendiğinde PAB konusunda çoğunlukla fen öğretimi hakkında fen bilgisi öğretmenleri ve sınıf öğretmenleri ile çalışmalar olmasına rağmen okul öncesi dönemde PAB'a yönelik çalışmalara rastlanmamış ve okul öncesi dönemde öğretmenlerin fen öğretimi konusundaki PAB'larına ilişkin bir bulguya ulaşılamamıştır. Bu sebeple katılımc1 öğretmene ait PAB bileşenlerinin birbiriyle olan etkileşimlerini ve aralarındaki ilişkileri keşfetmek için öğretim etkinliği ders planı, PAB görüşme soruları ve sinıf uygulamaları ele alınarak birlikte değerlendirilmiştir. Katılımcı Gözde öğretmenin genel olarak okul öncesinde fen öğretiminin yapılandırmacı yaklaşıma yönelik olması, öğrenme sürecinde çocuğu aktif kılınması gerektiğini ve sınıf içi uygulamaların önem kazandığını belirtmesine rağmen zaman zaman programın kazanım ve göstergelerine yönelik düşüncelerini ifade etmekte zorlandığını ve özellikle yeni programın içeriğine yabancı olduğunu ifade etmiştir. Düşünce olarak çocuğu merkeze alan bir öğretim sürecini öğrenme açısından etkili bulmakla birlikte programı uygulama konusunda kendisini yeterli görmediğini belirtmiştir. Bunun sebebinin lisans ve lisansüstü öğrenimleri boyunca almış oldukları pedagoji derslerine gereken önemin verilmemesine bağlayan Gözde öğretmen ders planı hazırlarken internete ve MEB programına ihtiyaç duyduğunu dile getirmiştir. Bu sonuç Ertürk, Özen-Altınkaynak, Veziroğlu ve Erkan'ın (2014) okul öncesi öğretmenlerinin üniversite deneyimlerinin mesleki yaşantılarına etkisine ilişkin görüşlerinin belirlenmesi amacıyla yaptıkları çalışmada elde ettikleri; öğretmenlerin 
lisans eğitimleri boyunca aldıkları birçok teorik ve pratik bilgiyi meslek yaşantılarında yansıtmada sorunlarla karşılaştıkları ve bu durumun temel nedeni olarak üniversite eğitimlerinde aldıkları derslerin içeriğini, uygulamaların süresi ve niteliğini, alanında uzman öğretim elemanı eksikliğini ifade ettikleri sonuçlarıyla uyum göstermektedir. Gözde öğretmenin kendisini fen öğretimi konusunda yetersiz görmesinin bir diğer sebebi ise uygulama yaptığı staj okullarında fen öğretimine dair iyi bir örneğe rastlamaması ve sınıflarında fen öğrenimi için yeterli materyalin bulunmamasıdır. Bu sonuç Karamustafaoğlu ve Kandaz'ın (2006) okul öncesi öğretmenlerinin fen etkinliklerinde kullandıkları yöntem ve teknikleri belirlemek ve bu uygulamaları yürütürken karşılaştıkları problemleri tespit etmek amacıyla gerçekleştirdikleri çalışmada elde ettikleri bulgularla benzerlik göstermektedir. Araştırmacılar okul öncesi öğretmenlerinin fen etkinliklerinin yapilabileceği materyallerin büyük bir çoğunluğunun yetersiz olduğu görüşünde birleştiklerini belirtmişlerdir. Bu durum uygulamalı etkinliklere yer verilmesini güçleştirmektedir. Gözde öğretmenin öğretim etkinliği ders planı ve PAB sorularına verdiği yanıtlarda etkili öğrenmeyi sağlamak için çocukların sürece etkin katılımını sağlaması gerektiğinden bahsetmiş ve bunun için çeşitli etkinliklerin kullanılmasının önemine vurgu yapmıştır. Ancak sınıf uygulamasına bakıldığında Gözde öğretmenin sahip olduğu görüşleri uygulamasına yansıtamadığı görülmüştür. Öğretim sürecinde ağırlıklı olarak öğretmen merkezli yaklaşım sergilediği ve belirlediği kazanımları çocuklara kazandırmak açısından etkili bir uygulama sergileyemediği görülmüştür.

Ön bilgilerinin belirlenmesinin gerekli olduğunu düşünen Gözde öğretmen bu sayede çocukların bilişsel anlamdaki yeterliliklerine bakarak öğretimi onların anlayabileceği şekilde gerçekleştirmenin daha uygun olacağını düşünmektedir. Aynı zamanda çocukları tanıma ve ön bilgilerini ortaya çıkarmanın etkili öğrenme için önemli olduğunu belirterek, çocukları tanıdıkça etkili öğrenmenin daha mümkün olacağını düşünmektedir. Fakat gerçekleştirdiği sınıf uygulamasında ön bilgileri tespit etmek amaciyla çocuklara genellikle belli bir kavramı tanımlamalarına yönelik soru sorduğu gözlenmiş olup bu bağlamda çocukların eleştirel düşünmelerini sağlayamadığı görülmüştür. Elde edilen bu sonuçlar Friedrichsen, Driel ve Abell'in (2011) araştırmalarında öğretmenlerin soru sormayı öğretim uygulamalarının bir parçası olduğunu düşündüklerini ve soru sormanın uygulama sırasında çocukların ön bilgilerini ortaya çıkarmak, öğretime karşı meraklarını tetiklemek ve seçilmiş olan konu alanı özelinde eksik kavramlarının neler olduğunu teşhis etmek amacıyla kullandıklarına ilişkin bir sonuç elde etmişlerdir. Böylece elde edilen sonuçlarla benzerlik gösterdiği söylenebilir.

Gözde öğretmenin oluşturmuş olduğu ders planı ve PAB görüşme sorularında verdiği yanıtlarda öğretim sürecinde kullanılan yöntem tekniklerin, ölçme ve değerlendirme yöntemlerinin konuya ve çocuklara uygun olarak seçilmesi, güncel yöntemlerin kullanılması gerektiğini dile getirmesine rağmen uygulama sürecinde soru cevap, düz anlatım ve deney tekniklerini sıklıkla kullanmayı tercih ettiği görülmüştür. Bu nedenle katılımcının sahip olduğu pedagoji bilgisini uygulamada kullanamadığı göze çarpmıştır. $\mathrm{Bu}$ anlamda okul öncesi literatürüne baktığımızda Karamustafaoğlu ve Kandaz (2006) yaptıkları çalışmanın sonucunda okul öncesi öğretmenlerinin fen kavramlarının çocuklara kavratılmasında kullandıkları yöntem ve tekniklerin daha çok anlatma, deney yapma gibi yöntemler olduğunu, değerlendirme sürecinde geleneksel yöntemlere başvurdukları sonucuna ulaşılmıştır. Böylelikle ulaşılan sonuçların benzerlik gösterdiği söylenebilir. Bütün bu sonuçlardan yola çıkılarak okul öncesi öğretmeni olan Gözde öğretmenin, çoğu zaman sahip olduğu bilgiyi uygulamaya yansıtamadığ için PAB'ının yeterli olmadığı sonucuna ulaşılmıştır. Araştırmada ulaşılan bu sonuçlar doğrultusunda şu öneriler verilebilir:

1. Okul öncesi öğretmenliği lisans programlarında verilen eğitim yalnızca teorik düzeyde kalmamalı, okul öncesinde fen eğitimi dersi uygulama saatleri arttırılarak her öğretmene meslek yaşantılarında kullanabilmeleri için güncel ve farklı metodlar hakkında bilgiler verilerek, öğretim süreçlerinde kullanmaları teşvik etmelidir.

2. Okul öncesi dönemde gerçekleştirilen fen öğretimlerinde farklı yöntem ve tekniklere başvurarak öğretim sürecine çocukların dahil edilmesi desteklenmelidir. 
3. Öğretmenler okul öncesi dönemde fen öğretiminde zengin öğrenme yaşantıları sunabilmek için gerekli ortam ve materyal desteği sağlanmalıdır.

4. Milli Eğitim Okul Öncesi Müfredatı'nda değişikliklere gidilerek öğretmenlere, öğretim görevlilerine çocukların anlamakta zorlanacakları konuları, belirlenen konuya yönelik hangi öğretim yöntemleri ile daha etkili bir öğretim gerçekleştireceklerine yönelik gerekli rehberliğin yapılması sağlanmalıdır.

5. Özellikle öğretim programları değişikliklerin yaşandığ 1 geçiş dönemlerinde, öğretmenlere yeni müfredat ile ilgili müfredatın dayandığı temeller, değişikliğin sebepleri, müfredatın hedefleri, çocukların öğrendiklerinin nasıl ölçüleceği konularında gerekli destek sağlanmalıdır.

6. Farklı durumların (yaş, mezun olduğu okul, görev yaptı̆̆ 1 semt, vb.) okul öncesi öğretmenlerinin fene yönelik PAB düzeylerini etkileyip etkilemediğini incelemeye ve karşılaştırmaya yönelik çalışmalar yapabilir.

7. Farklı konu bağlamları (oyun, matematik etkinlikleri, drama, vb.) üzerinden okul öncesi öğretmenlerinin PAB düzeyleri incelenebilir.

\section{Etik Kurul Onay Bilgileri}

İstanbul Aydın Üniversitesi Rektörlüğü Lisansüstü Eğitim Enstitüsü Müdürlüğü, 28.01.2020, 88083623-020

\section{Kaynaklar}

Abell, S. K., Rogers, M. A. P., Hanuscin, D. L., Lee, M. H. ve Gagnon, M. J. (2009). Preparing the next generation of science teacher educators: a model for developing pck for teaching science teachers. Journal of Science Teacher Education, 77-93.

Aktaş Arnas, Y., Aslan, D. ve Bilaloğlu, R. G. (2014). Okul öncesi dönemde fen eğitimi. Ankara: Vize Yayıncilık.

Baxter, J. A., ve Lederman, N. G. (1999). Assessment and measurement of pedagogical content knowledge. Examining Pedagogical Content Knowledge, 147-161.

Darling-Hammond, L. ve Baratz-Snowden, J. (2005). A good teacher in every classroom: Preparing the highly qualified teachers our children deserve. San Francisco: JosseyBass.

De Jong, O. (2003). Exploring science teachers' pedagogical content knowledge. Science Education Research in the Knowledge Based Society, içinde (ss. 373-381). Dordrecht, The Netherlands: Kluwer Academic Publishers.

DeVellis, R. F. (2012). Scale development: Theory and applications. USA: Sage Publications.

Ertürk, G., Altınkaynak, Ş. Ö., Veziroğlu, M. ve Erkan, S. (2014). Okul öncesi öğretmenlerin üniversite deneyimlerinin mesleki yaşantılarına etkisine ilişkin görüşlerinin belirlenmesi. Kastamonu Eğitim Dergisi, 897-908.

Faikhamta, C., Coll, R. K. ve Roadrangka, V. (2009). The development of Thai pre-service chemistry teachers' pedagogical content knowledge: From a methods course to field experience. Journal of Science and Mathematics Education in Southeast Asia, 18-35.

Flick, U. (2018). Triangulation in data collection. The SAGE Handbook of Qualitative Data Collection. London, UK: SAGE Publications.

Fraenkel, J. R. ve Wallen, N. E. (2006). How to design and evaluate research in education . USA: McGrawHill.

Glaser, B. ve Strauss, A. (1967). The discovery of grounded theory. 1967. Weidenfield \& Nicolson, London, 1-19.

Güvenir, Z. (2018). Okul öncesi öğretmenlerinin fen öğretimine yönelik tutumları ile okul öncesi eğitim programında yer alan fen etkinliklerini uygulama durumları. Yüksek Lisans Tezi, Uşak Üniversitesi, Uşak.

Jones, A. ve Moreland, J. (2005). The importance of pedagogical content knowledge in assessment for learning practices: a case-study of a whole-school approach. The Curriculum Journal, 193-206. 
Kahraman, G. Ö., Ceylan, Ş. ve Ülker, P. (2015). Bilimi yaratan duygu: çocukların fen ve doğaya ilişkin konulardaki bilgi ve merakları. Türkiye Sosyal Araştırmalar Dergisi, 207-229.

Karamustafaoğlu, Sevilay ve Ufuk Kandaz. (2006). Okul öncesi eğitimde fen etkinliklerinde kullanılan öğretim yöntemleri ve karşılaşılan güçlükler. Gazi Eğitim Fakültesi Dergisi, 65-81.

Kleickmann, T., Richter, D., Kunter, M., Elsner, J., Besser, M., Krauss, S. ve Baumert, J. (2013). Teachers' content knowledge and pedagogical content knowledge: The role of structural differences in teacher education. Journal of teacher education, 90-106.

Korthagen, F. A. ve Kessels, J. P. (1999). Linking theory and practice: Changing the pedagogy of teacher education. Educational researcher, 4-17.

Leedy, P. D. ve Ormrod, J. E. (2001). Practical research: planning and design, merrill prentice hall. New Jersey.

Magnusson, S., Krajcik, J. ve Borko, H. (1999). Nature, sources and development of pedagogical content knowledge for science teachin, içinde (ss. 95-132). Dordrecht, The Netherlands: Kluwer Academic Publishers.

Park, J. ve Oliver, J. S. (2008). National Board Certification (NBC) as a catalyst for teachers' learning about teaching. The Effects of the NBC Process on Candidate Teachers' PCK Development. Journal of Research in Science Teaching, 812-834.

Patton, M. Q. (2014). Qualitative research \& evaluation methods: Integrating theory and practice. Sage publications.

Sak, R., Tantekin-Erden, F. ve Morrison, G. S. (2018). Preschool teachers' beliefs and practices related to child-centred education in Turkey. Education, 563-577.

Sansar, S. B. (2010). Okul öncesi öğretmenlerinin fen öğretimine yönelik tutumları ile fen eğitiminde kullandıkları yöntemler arasındaki ilişkinin incelenmesi (Yüksek lisans tezi). Abant İzzet Baysal Üniversitesi, Bolu

Sığırtmaç, A. ve Özbek, S. (2011). Okul öncesi öğretmenlerinin fen eğitimine ilişkin görüşleri ve uygulamalarının incelenmesi. e-Journal of New World Sciences Academy, 10391056.

Sundqvist, P. ve Nilsson, T. (2018). Technology education in preschool: Providing opportunities for children to use artifacts and to create. International Journal of Technology and Design Education, 29-51.

Thomas, E. ve Magilvy, J. K. (2011). Qualitative rigor or research validity in qualitative research. Journal for specialists in pediatric nursing, 151-155.

Thulin, S. ve Redfors, A. (2017). Student preschool teachers' experiences of science and its role in preschool. Early Childhood Education Journal, 509-520.

Uludağ, G. (2017). Okul dışı öğrenme ortamlarının fen eğitiminde kullanılmasının okul öncesi dönemdeki çocukların bilimsel süreç becerilerine etkisi (Yüksek lisans tezi). Hacettepe Üniversitesi, Ankara.

Yıldırım, A. ve Şimşek, H. (2013). Sosyal bilimlerde nitel araştırma yöntemleri. Ankara: Seçkin Yayınevi.

Yin, R. K. (2017). Case study research and applications: Design and methods. Sage publications.

\section{Extended Abstract}

\section{Introduction}

Children feel the need to recognize and understand everything happening around them and interpret their world starting from birth. Thanks to this inherent curiosity, they acquire some simple scientific skills. Their efforts to recognize and interpret their environments with this curiosity are the first scientific experiences of their lives (Aktaş-Arnas, Aslan \& Bilaloğlu, 2014). Preschool teachers play a key role in enabling children to develop scientific thoughts and exhibit positive attitudes to science lessons in primary and middle school years (Thulin \& 
Redfors, 2017). Knowledge, views, attitudes and self-efficacy of preschool teachers with regard to science studies are highly important in terms of children's attitudes to science studies. However, an analysis of national and international literature indicates that no studies are available on their PCKs, the teaching proficiency that preschool teachers need to have to teach effectively. Especially preschool teachers who are children's first teachers must have the necessary knowledge on their learning and development, knowledge on the purposes of curriculum and knowledge on teaching in order to adapt to the ever-changing world (DarlingHammond \& Baratz-Snowden, 2005). Therefore, the PCK of preschool teachers in particular is a topic that should be elaborated further and given importance.

\section{Method}

In this study where the pedagogical content knowledge of a preschool teacher on science teaching was explored, single case study which is one of the qualitative research approaches was used. In selection of the participant teacher, criterion sampling which is one of the purposeful sampling methods was used and a preschool teacher who continued her master's degree education was selected, and data collected was initiated after she agreed to participate in the study. In order to ensure variation which is one of the important strategies for reliability and validity in qualitative studies, three different data collection tools were used to thoroughly describe the pedagogical content knowledge of the teacher who participated in the study. Firstly, the participant teacher was asked to create a Teaching Activity Lesson Plan on a subject of her choice, then she was asked to answer the PCK Interview Questions which were prepared according to the five PCK components as described by Magnusson, Krajick and Borko (1999) and finally she was asked to implement her lesson plan. In doing this, the Observation technique was used. Responses obtained from the data collection tools were analyzed by using inductive content analysis. In the last stage of analysis, the participant teacher was asked to implement her lesson plan and data acquired during implementation was recorded in the observation rubric. As a result of the data recorded in the observation rubric, the teacher's responses to the questions regarding her lesson plan and to PCK interview questions were compared and thus, findings were obtained with regard to the pedagogical content knowledge of a preschool teacher on science teaching and also the connection of the teacher's PCK elements was determined.

\section{Findings}

Study findings indicate that the preschool teacher who was receiving a master's degree education thought that she lacked proficiency in science teaching, the shortage of teaching materials affected the teaching process negatively and a teacher-centered process where the children played a passive role was dominant. During the implementation of the lesson plan, it was observed that the teacher had general knowledge of curriculum but could not apply her theoretical knowledge into practice. Furthermore, when her teaching strategies and assessment methods in teaching process were evaluated, it can be said that she was unable to catch up with the current methods and applied conventional strategies and assessment methods.

\section{Discussion and Conclusion}

Although the participant teacher specified that science teaching should be generally based on a constructive approach, children should be actively engaged in teaching process and in-class practices were important, she stated that she had difficulty in expressing her thoughts on the learning outcomes and indicators of the curriculum and that she was unfamiliar especially with the new curriculum content and thus felt that she lacked proficiency in implementing the curriculum. She expressed that it was because pedagogy lessons were not given due importance throughout their undergraduate and postgraduate studies. This result is compatible with the results of a study conducted by Ertürk, Özen-Altınkaynak, Veziroğlu and Erkan (2014) to determine the views of preschool teachers about the effect of university experience on their professional lives, in which it was determined that teachers had problems with applying the theoretical and practical knowledge they had learnt throughout their undergraduate education 
into their professional lives and expressed that it was mainly because of the content of their courses, the duration and quality of practices and the shortage of instructors who were experts in their fields. The participant emphasized that children should be actively engaged in the learning process to ensure effective learning and therefore various activities should be used in her responses to PCK interview questions and the teaching activity lesson plan questions. However, in her in-class practices, it was observed that she failed to put her views into practice. It was seen that she mainly adopted a teacher-centered approach in teaching processes and failed to practice an effective teaching process to achieve the predetermined outcomes. It was observed that the results were incompatible with the results of a study conducted by Sığırtmaç and Özbek (2011) who reported that preschool teachers included children in the learning process by using various activities and they reached the final result together. In the light of all these results, it was concluded that the PCK of the preschool teacher participant who continued her master's degree education was not adequate because she could not put her theoretical knowledge into practice most of the time.

\section{EK-1: Öğretim Etkinliği Ders Planı \\ Bilimsel Süreç Becerileri:}

Konu Alanı:

Kazanım(lar):

\section{Büyük Fikir-1:}

\section{Büyük Fikir-2:}

\section{Konunun Alt Düşünceleri:}

S1 Çocukların bu büyük fikirler hakkında ne öğrenmesini istiyorsunuz?

S2 Çocukların bu büyük fikirleri öğrenmesi neden önemlidir?

S3 Çocuklar bu büyük fikirleri öğrenirken hangi zorluklarla karşılaşabilir?

S4 Çocukların bu büyük fikirler hakkında nitelikli bir anlayış geliştirmelerine yardımcı olmak için hangi öğretim stratejisi veya özel etkinlikler kullanılabilir?

S5 Okul öncesi eğitim müfredatında büyük fikirlerinizle ilgili ne tür kazanımlar vardı?

S6 Çocukların bu büyük fikirleri anlayıp anlamadıklarını belirlemek için ne yapıyorsunuz?

\section{EK-2: Pedagojik Alan Bilgisi (PAB) Görüssme Soruları}

Giriş Soruları

1. Sınıfınızda herhangi bir fen öğretim etkinliğini (seçtiğiniz konu alanı özelinde) nasıl gerçekleștirirsiniz?

2. Kendinizi bu konu alanına yönelik fen öğretimini gerçekleştirme konusunda yeterli görüyor musunuz? Neden?

PAB Bileşenleri

1. Sizce çocukları bu konu alanı özelindeki bir fen öğretimine neden dâhil etmeliyiz? (Öğretime yönlendirme)

a. Belirttiğiniz bu amaçları/hedefleri nasıl belirlediniz?

b. Öğrencilerin bu süreç sonunda öğrendiklerini nasıl ve nerede kullanmalarını beklersiniz?

c. Öğrencilerin bu süreç sonunda öğrendiklerinin günlük hayatlarında işlerine yarayacağını düşünüyor musunuz?

2. Sizce çocuğun bu konu alanı özelindeki fen öğretiminde nitelikli öğrenmeler gerçekleştirebilmesi için neye ihtiyaçları olabilir? Neden? (ön bilgiler, beceriler) (Öğrenci anlayışları bilgisi)

a. Sizce çocuklar bu süreçte ne tür zorluklar yaşayabilirler? Neden? 


\begin{tabular}{|c|c|c|c|c|c|}
\hline \multicolumn{6}{|c|}{ EK-3: Gözde Öğretmenin Kavramsallaştırmaları } \\
\hline \multicolumn{4}{|c|}{ Ders Planı } & \multicolumn{2}{|c|}{ Görüşme } \\
\hline \multirow{5}{*}{ 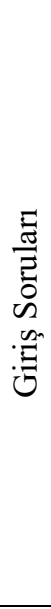 } & \multirow{5}{*}{ 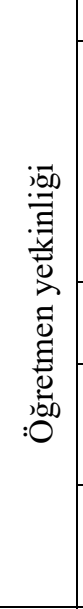 } & Temalar & Kavramlar & Temalar & Kavramlar \\
\hline & & $\begin{array}{l}\text { Sosyal-Duygusal } \\
\text { alan gelişimi }\end{array}$ & $\begin{array}{c}\text { Farklılilara tolerans } \\
\text { gösterme } \\
\text { Kendi özelliklerini fark } \\
\text { etme } \\
\text { Olumlu benlik algısı } \\
\text { geliştirme }\end{array}$ & Üst bilişsel süreç becerileri & $\begin{array}{c}\text { Akılda tutma } \\
\text { Farklılıkları ayırt etme } \\
\text { Farklı durumları karşılaştırma }\end{array}$ \\
\hline & & $\begin{array}{l}\text { Öğretmen } \\
\text { yetkinliği }\end{array}$ & Öz eleştiri & Duyuşsal alan gelişimi & $\begin{array}{l}\text { Çocuğun motivasyonunu arttırma } \\
\text { Merak duygusunu güdüleme }\end{array}$ \\
\hline & & $\begin{array}{l}\text { Öğretim öncesi } \\
\text { hazırlık ve uygun } \\
\text { materyal seçimi }\end{array}$ & Materyal yetersizliği & Öğretmen merkezli yaklaşım & Anlatma yöntemini kullanma \\
\hline & & Müfredat bilgisi & Öğretimde yetersizlik & $\begin{array}{l}\text { Öğretimde firsatları } \\
\text { değerlendirme }\end{array}$ & $\begin{array}{c}\text { Sinıf yönetimi } \\
\begin{array}{c}\text { Değişen durumlara yönelik } \\
\text { stratejiler kullanma }\end{array} \\
\end{array}$ \\
\hline \multirow{13}{*}{ 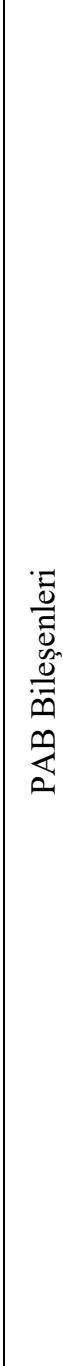 } & \multirow{4}{*}{ 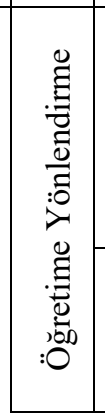 } & \multirow[b]{2}{*}{$\begin{array}{l}\text { Farklılıklara karşı } \\
\text { farkındalık } \\
\text { oluşturma }\end{array}$} & \multirow{2}{*}{$\begin{array}{c}\text { Farklılılara tolerans } \\
\text { gösterme } \\
\text { Kendi özelliklerini fark } \\
\text { etme } \\
\text { Olumlu benlik algısı } \\
\text { geliştirme }\end{array}$} & $\begin{array}{c}\text { Üst bilişsel süreç becerilerini } \\
\text { destekleme }\end{array}$ & $\begin{array}{c}\text { Farklılıkları ayırt etme } \\
\text { Farklı durumları karşılaştırma }\end{array}$ \\
\hline & & & & $\begin{array}{l}\text { Bilginin yapılandırılması ve } \\
\text { transferi }\end{array}$ & $\begin{array}{l}\text { Bilgiye ulaşma } \\
\text { Bilgiyi günlük hayatta kullanma }\end{array}$ \\
\hline & & & & Öğretmen merkezli yaklaşım & Deneyle anlatma \\
\hline & & $\begin{array}{l}\text { Bilginin } \\
\text { aktarılmas1 }\end{array}$ & $\begin{array}{l}\text { Bilgiyi günlük hayatta } \\
\text { kullanma }\end{array}$ & $\begin{array}{c}\text { Farklılıklara karşı farkındalık } \\
\text { oluşturma }\end{array}$ & $\begin{array}{c}\text { Farklılıları kabullenmeme } \\
\text { Kendi özelliklerini fark etme } \\
\text { Olumlu benlik algısı geliştirme }\end{array}$ \\
\hline & \multirow[t]{2}{*}{ 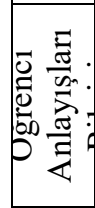 } & \multirow[t]{2}{*}{$\begin{array}{l}\text { Bilişsel } \\
\text { olgunluğa ulaşma }\end{array}$} & \multirow[t]{2}{*}{$\begin{array}{l}\text { Farklı durumlar arasında } \\
\text { bağlantı kurma }\end{array}$} & Bilişsel olgunluğa ulaşma & $\begin{array}{c}\text { Kiyaslama yapabilme } \\
\text { Akıl yürütme } \\
\text { Farklı durumlar arasında bağlantı } \\
\text { kurma }\end{array}$ \\
\hline & & & & Duyuşsal alan gelişimi & Çocukların motivasyonunu arttırma \\
\hline & \multirow{2}{*}{ 旁: } & $\begin{array}{l}\text { Müfredat } \\
\text { yetkinliği }\end{array}$ & $\begin{array}{c}\text { Uygun kazanımlara yer } \\
\text { verme }\end{array}$ & & \multirow{2}{*}{$\begin{array}{c}\text { Kazanım ve göstergeler hakkında } \\
\text { yeterli bilgiye sahip olma } \\
\text { Uygun kazanımlara yer verme }\end{array}$} \\
\hline & & $\begin{array}{l}\text { Kazanım odaklı } \\
\text { yaklaşım }\end{array}$ & $\begin{array}{c}\text { Kazanımları } \\
\text { gerçekleştirmeyi } \\
\text { hedefleme }\end{array}$ & Müfredat yetkinliği & \\
\hline & \multirow{2}{*}{ 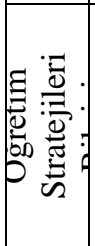 } & \multirow{2}{*}{$\begin{array}{l}\text { Öğretimde } \\
\text { geleneksel } \\
\text { stratejilere } \\
\text { başvurma }\end{array}$} & \multirow[t]{2}{*}{$\begin{array}{l}\text { Deneyle anlatım yöntemi } \\
\text { Soru cevap yöntemi } \\
\text { kullanma }\end{array}$} & $\begin{array}{l}\text { Öğretimde geleneksel } \\
\text { stratejilere başvurma }\end{array}$ & $\begin{array}{l}\text { Deneyle anlatım yöntemini } \\
\text { kullanma } \\
\text { Gösterip anlatma yöntemini } \\
\text { kullanma }\end{array}$ \\
\hline & & & & $\begin{array}{l}\text { Öğretim sürecinde iç } \\
\text { motivasyonu arttırma }\end{array}$ & Merak duygusunu güdüleme \\
\hline & \multirow{3}{*}{ 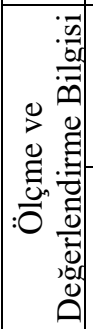 } & $\begin{array}{l}\text { Öğretimde } \\
\text { geleneksel } \\
\text { stratejilere } \\
\text { başvurma }\end{array}$ & $\begin{array}{l}\text { Soru cevap yöntemi } \\
\text { kullanma }\end{array}$ & Bilgiyi transferi etme & Bilgiyi günlük hayatta kullanma \\
\hline & & \multirow{2}{*}{$\begin{array}{c}\text { Bilişsel } \\
\text { olgunluğa ulaşma }\end{array}$} & \multirow{2}{*}{$\begin{array}{c}\text { Farklı1ıkları ayırt edebilme } \\
\text { Gözlem yapma }\end{array}$} & $\begin{array}{l}\text { Öğretimde geleneksel } \\
\text { stratejilere başvurma }\end{array}$ & Soru cevap yöntemi kullanma \\
\hline & & & & Bilişsel olgunluğa ulaşma & $\begin{array}{l}\text { Farklı durumlar arasında bağlantı } \\
\text { kurma }\end{array}$ \\
\hline
\end{tabular}

